Pamiętnik Literacki 2020, 1, s. 265-269

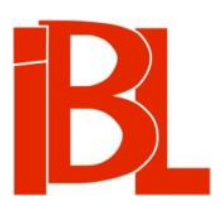

Mieczysław Inglot

(11 stycznia 1931 - 24 marca 2019)

Marian Ursel 


\section{MIECZYSŁAW INGLOT (11 stycznia 1931 - 24 marca 2019) WSPOMNIENIE}

Profesor Mieczysław Inglot urodził się 11 stycznia 1931 we Lwowie. Jego rodzicami byli profesor Stefan Inglot, badacz historii gospodarczej i społecznej, oraz Mieczysława $z$ domu Rozenhnal. Familia Inglotów wywodzi się od niemieckich osadników, którzy w XIV wieku znaleźli swe miejsce we wsi Albigowa. Mieczysław Inglot mieszkał we Lwowie do chwili, gdy w 1942 roku przeniósł się wraz z rodzicami do Albigowej - jak wspominał w wywiadzie dla Magdaleny Bajer - wsi „postępowej”, gdzie żyli jego dziadkowie. Tam też podjął naukę na tajnych kompletach. Po wojnie - już w Krakowie - został uczniem IV Liceum i Gimnazjum im. Henryka Sienkiewicza. Świadectwo maturalne otrzymał w 1949 roku. Następnie rozpoczął na Uniwersytecie Jagiellońskim studia polonistyczne, które ukończył w 1954 roku. Już wtedy pociagała go wyraźnie droga naukowa. Na krakowskim uniwersytecie kontynuował studia aspiranckie. Został zatrudniony w 1957 roku w Katedrze Literatury Polskiej Uniwersytetu Wrocławskiego. Początkowo jako starszy asystent, a następnie jako adiunkt. Ważnym argumentem przy wyborze Wrocławia była nie tylko wysoka pozycja polonistyki wrocławskiej, ale i piękne oczy Anny Dubowskiej, poznanej w 1953 roku w Ostródzie na zjeździe Studenckich Kół Naukowych.

W roku 1959 obronił na Uniwersytecie Jagiellońskim dysertację doktorską pt. Poglady literackie koterii petersburskiej $w$ latach 1832-1851, której promotorem był prof. Kazimierz Wyka. Postać Mistrza uniwersyteckiego często pojawiać się będzie w wypowiedziach i wspomnieniach Inglota. W roku 1965 na Uniwersytecie Wrocławskim uzyskał on stopień doktora habilitowanego na podstawie rozprawy Polskie czasopisma literackie ziem litewsko-ruskich w 1832-1851. Rok później otrzymał stanowisko docenta. Od roku 1972 kierował Zakładem Nauczania Języka i Literatury Polskiej (następnie przekształconego w Zakład Metodyki Nauczania Języka i Literatury Polskiej) w Instytucie Filologii Polskiej Uniwersytetu Wrocławskiego. W roku 1976 mianowany został profesorem nadzwyczajnym, a w 1984 roku profesorem zwyczajnym w zakresie nauk humanistycznych.

W maju 2018 Profesor wystapił z pomysłem przygotowania i wydania - z okazji 50-lecia istnienia Zakładu - specjalnego numeru „Prac Literackich”, polonistycznego czasopisma naukowego, które ukazuje się we Wrocławiu od 1956 roku (jako redaktor naczelny rozmawiałem na ten temat $z$ Profesorem). Niestety, śmierć nie pozwoliła mu na zrealizowanie tego pomysłu (Choć warto wspomnieć, że projekt nie przepadł - jego kontynuacji podjęła się dr hab. Dorota Michułka, uczennica Inglota).

W latach 1966-1969 wykładał też Inglot w Opolskiej Wyższej Szkole Pedagogicznej. Pracował także w Katedrze Dziennikarstwa i Komunikacji Społecznej 
w Wyższej Szkole Zarządzania „Edukacja” we Wrocławiu oraz w Katedrze Filologii w Wyższej Szkole Zarządzania Marketingowego i Języków Obcych w Katowicach.

Od roku 1972 do 1987 wchodził w skład Zarządu Głównego Towarzystwa im. Marii Konopnickiej, od 1957 roku należał do Towarzystwa Literackiego im. Adama Mickiewicza, w okresie 1966-1987 pełnił funkcję prezesa Oddziału Wrocławskiego, od 1981 roku także przewodniczącego Komisji Rewizyjnej Towarzystwa. Od roku 1966 był członkiem Wrocławskiego Towarzystwa Naukowego, a w 1992 roku został jego wiceprezesem.

W latach 1973-1990 współpracował z Wrocławskim Oddziałem Instytutu Kształcenia Nauczycieli i Badań Oświatowych, od 1974 roku był przewodniczaccym Okręgowego Komitetu Olimpiady Literatury i Języka Polskiego dla szkół średnich we Wrocławiu. W okresie 1975-1990 należał do Rady Naukowej Biblioteki Zakładu Narodowego im. Ossolińskich, w tym, w latach 1981-1984, pełnił funkcje jej przewodniczącego, a od roku 1987 do 1990 - wiceprzewodniczącego.

W latach 1981-1983, 1987-1990 i 2000-2003 był członkiem Komitetu Nauk o Literaturze Polskiej Akademii Nauk, a w latach 1976-1986 członkiem Komisji Historii Prasy przy Komitecie Nauk Historycznych PAN.

W roku 1978 został radnym Dzielnicowej Rady Narodowej Wrocław - Stare Miasto, którą to funkcje pełnił do 1984 roku.

W roku 1957 ożenił się z młodą lekarką Anną Dubowską, która w przyszłości zostanie wybitnym hematologiem. Niestety, zmarła ona przedwcześnie w 1998 roku. Mieli dwoje dzieci: syna Tomasza i młodszą od niego córkę Dorotę. Tomasz, mocno związany z patriotycznymi ruchami studenckimi, internowany w czasie stanu wojennego otrzymał następnie paszport w jedną stronę i wyjechał do Stanów Zjednoczonych Ameryki, gdzie zrobił karierę naukową. Po roku 1989, w innej już sytuacji politycznej, zaczął odwiedzać rodzinny kraj, kiedy tylko było to możliwe. Dorota ukończyła wrocławską polonistykę oraz anglistykę. Odżegnywała się jednak zdecydowanie od drogi naukowej swych rodziców, podejmując pracę w zawodzie nauczycielskim.

Był Mieczysław Inglot wybitnym literaturoznawca: historykiem literatury polskiej, badaczem romantyzmu, edytorem wielkich tekstów romantycznych, a ponadto cenionym dydaktykiem, znakomitym nauczycielem języka polskiego i literatury. Mógł poszczycić się niezwykle bogatym i znaczącym dorobkiem naukowym, dydaktycznym oraz edytorskim. Nikt do tej pory nie zestawił pełnej bibliografii jego prac. W księdze dedykowanej mu z okazji siedemdziesiątych urodzin dr Aleksander Kuzik z Instytutu Filologii Polskiej Uniwersytetu Wrocławskiego opracował bibliografię za lata 1950-2000, która liczyła 481 pozycji. Na liście bibliograficznej na stronie Instytutu Filologii Polskiej wymienionych jest kolejnych 90 jego prac, powstałych w latach 2001-2010. Jakie publikacje ukazały się po 2010 roku do śmierci Profesora, nie wiemy. Ustalenie tego i zweryfikowanie całości to zadanie przyszłego biografa i bibliografa dorobku naukowego Inglota. A warto też pamiętać, że w latach pięćdziesiątych XX wieku pisywał on i publikował również wiersze. Spod jego pióra wyszło blisko 30 książek. Podejmowały one najważniejsze wątki związane $z$ twórczością wielkich romantyków polskich, takich jak Adam Mickiewicz, szczególnie ulubiony Juliusz Słowacki, ciągle zapoznany Seweryn Goszczyński, 
nowatorsko czytany i interpretowany Cyprian Norwid czy Aleksander Fredro, którego pisarstwo Profesor analizował wielostronnie. Dał się też poznać jako wytrawny edytor i komentator takich dzieł m.in., jak Fredry Dożywocie, Śluby panieńskie, Zemsta, Goszczyńskiego Król zamczyska, Krasińskiego Nie-Boska komedia, Słowackiego Fantazy i Balladyna, Norwida Wybór wierszy.

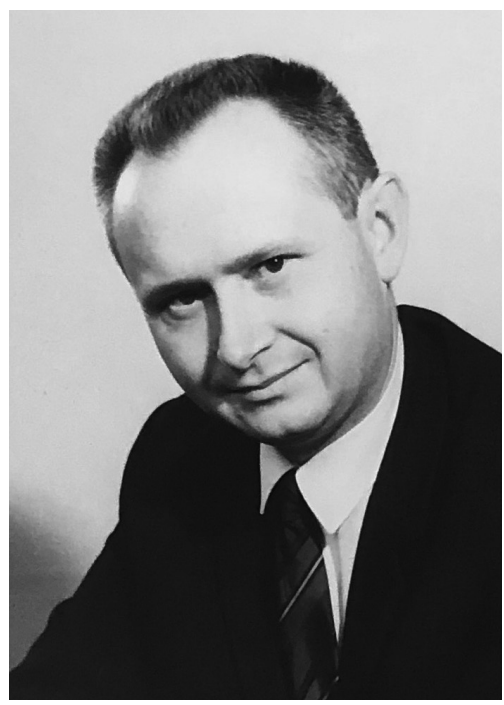

Mieczysław Inglot

Za swoją działalność naukową, edukacyjną i społeczną został Mieczysław Inglot uhonorowany Medalem Budowniczego Wrocławia, Medalem Komisji Edukacji Narodowej (1976) oraz Krzyżem Kawalerskim Orderu Odrodzenia Polski (1978).

Po tych szkicowych biograficznych informacjach dotyczących dorobku naukowego Profesora oraz jego sylwetki jako badacza chciałbym przywołać garść wspomnień, które ukazują go w mniej oficjalnym wymiarze, właściwym dla poetyki tego typu wypowiedzi. Odwołuję się w tym fragmencie do wydarzeń, których najczęściej byłem uczestnikiem lub usłyszałem o nich od pracowników Instytutu Filologii Polskiej Uniwersytetu Wrocławskiego.

Po przyjeździe do Wrocławia w 1957 roku Inglot szybko został zaakceptowany przez „mikulczyków”, uczniów prof. Tadeusz Mikulskiego, ówczesnego szefa polonistyki wrocławskiej. Ważnym czynnikiem była tu przyjaźn łącząca Kazimierza Wykę z Mikulskim. Proces adaptacji Inglota w środowisku wrocławskim nie przebiegał jednak bezproblemowo. Dziennikarz i młody ideolog Bogdan Bąk zaatakował kiedyś prof. Bogdana Zakrzewskiego, kierownika Katedry Historii Literatury Polskiej, iż zatrudnił „pana importowanego z Krakowa”, miasta uznawanego przez ówczesnych marksistów za ostoję sił burżuazyjnych.

Profesora Inglota cechowała życzliwość wobec ludzi, starał się pomagać im w trudnych sytuacjach. Gdy w roku 1960 kierowniczka biblioteki katedralnej, aby 
otrzymać mieszkanie, musiała wpłacić kaucję w wysokości 6000 złotych - a stanowiło to kwotę zawrotną dla młodej bibliotekarki, zarabiającej 2000 złotych miesięcznie, co ledwie pozwalało wiązać koniec z końcem - człowiekiem, który jej wtedy pomógł, pożyczając ową sumę, był Inglot. Od tej pory mieszkanie to było miejscem spotkań towarzyskich części pracowników. Bywanie tam uważano za wyróżnienie. Gdy przyszedł czas na remont, przeprowadzili go właśnie stali bywalcy (pod moją wodza), a po wykonaniu wszystkich prac gospodyni podjęła nas smakołykami, Profesor Inglot zaś - zgodnie z tradycją - jak dawny podczaszy otworzył butelkę wina, napełnił kieliszki i następnie wzniósł toast za pomyślne ukończenie remontu.

Spotkania towarzyskie pracowników Instytutu odbywały się też w stołówce Biblioteki Ossolineum, gdzie niejednokrotnie widywało się Inglota prowadzącego dysputę np. z Romanem Kaletą czy Romanem Sobolem lub prof. Władysławem Floryanem. Jednak miejscem szczególnie popularnym była biblioteka instytutowa, a zwłaszcza gabinet jej kierowniczki, w którym chętnie przesiadywali pracownicy, dyskutujacc w przerwach pomiędzy zajęciami.

Inglot bardzo lubił dzieci i chętnie je widywał w towarzystwie rodziców, których od czasu do czasu do siebie zapraszał. Pamiętam dobrze, kiedy w czerwcu 2001 zorganizowano w klubie uniwersyteckim uroczystość z okazji jego siedemdziesiątych urodzin, połączoną $z$ wręczeniem księgi pamiątkowej, zredagowanej przez prof. Władysława Dynaka. W uroczystości tej uczestniczyły także dzieci pracowników (wśród nich dwie moje córki), które były przez Profesora zachęcane do zabawy, czasem nawet zbyt dynamicznej. „Bohaterem” uroczystości był żurek, podawany w małych bochenkach zakopiańskiego chleba, którym delektował się zarówno Profesor (znany wśród przyjaciół i pracowników jako smakosz), jak i jego goście.

Profesor Inglot miał zwyczaj w czasie rozmowy, ale także wystąień publicznych zamykać oczy i kręcić guzik od marynarki. W zależności od tematu, charakteru i stosunku emocjonalnego malowała się na jego twarzy albo aprobata, albo niechęć czy zdegustowanie. Chętnie też zabierał głos na różnych spotkaniach naukowych. Zadawał - dość często, np. podczas obron doktorskich czy kolokwiów habilitacyjnych - pytania niekiedy dość kłopotliwe dla pytanego. Tym bardziej że obudowane były obszerną dygresją.

Z pozoru dość zasadniczy, był Inglot człowiekiem towarzyskim i dowcipnym. Jego talent do opowiadania anegdot objawił się w latach osiemdziesiątych. Ze szczególnym upodobaniem Profesor serwował słuchaczom dowcipy polityczne. Gromadził je i po latach wydał w formie antologii. Kiedyś na zajęciach ze studentami opowiadał o sobie i z rozbawieniem wyznał, że w szkole nazywano go Mewą, nie wyjaśnił jednak - dlaczego.

Z Profesorem Inglotem po raz pierwszy spotkałem się osobiście 5 marca 1973. Był to dzień obrony mojej pracy magisterskiej, która on recenzował, a promował mój Mistrz, prof. Bogdan Zakrzewski. Później Inglot był też recenzentem dysertacji doktorskiej i uczestniczył w moim kolokwium habilitacyjnym. Pytał mnie wtedy pamiętam dobrze, choć minęło ponad ćwierć wieku - o bajkopisarstwo Morawskiego. W jakiś czas potem w trakcie rozmowy telefonicznej zaproponował przejście na ty. Było to dla mnie spore przeżycie. Dużym przeżyciem było także to, że kiedyś, 
po konferencji naukowej w Jarosławiu poświęconej Fredrze, poszedłem z nim (i z prof. Zakrzewskim) do restauracji na piwo.

I jeszcze jedno migwkowe wspomnienie. Wiosną 2019 Profesor Inglot zadzwonił do mnie i zadeklarował przekazanie części swego księgozbioru bibliotece Karkonoskiej Państwowej Szkoły Wyższej w Jeleniej Górze, z którą był od lat związany. Uczelnia otrzymała około 900 woluminów. Jako rektor z ogromną wdzięcznością przyjąłem ten cenny dar.

Zmarł Profesor dr habilitowany Mieczysław Inglot we Wrocławiu 24 marca 2019, przeżywszy 88 lat.

Marian Ursel

Uniwersytet Wrocławski - University of Wrocław

ORCID: 0000-0001-6952-9146

Abstract

OBITUARY: MIECZYSŁAW INGLOT (January $11^{\text {th }}, 1931-$ March $24^{\text {th }}, 2019$ )

A REMEMBRANCE

The remembrance is devoted to professor Mieczysław Inglot, an outstanding specialist in Polish Romantic literature and its meritorious populariser, researcher mainly in Juliusz Słowacki's and Aleksander Fredro's creativity, and editor of their output. The professor's field of interest also included so-called minor authors' home literature 1832-1863. His great achievements are also found in the methodology of Polish literature teaching. He supervised many masters of arts and doctors of philosophy in the field of humanities.

Professor Inglot died aged 88. 